\title{
Somatic growth in juveniles of the estuarine crab Chasmagnathus granulata Dana 1851 (Brachyura, Grapsidae), under laboratory conditions
}

\author{
Laura S. López and Enrique M. Rodríguez \\ Lab. of Animal Physiology, Dept. of Biological Sciences, University of Buenos Aires, Ineuci-Conicet. \\ Ciudad Universitaria, Pab. II, 1428 Buenos Aires, Argentina. \\ E-mail: laura@biolo.bg.fcen.uba.ar
}

\begin{abstract}
Male and female juvenile crabs of the species Chasmagnathus granulata were collected in Samborombón Bay (Argentina), on October 1994 and February 1995; these dates correspond to the beginning and end of the reproductive period of the species, respectively. No differences in the initial size (measured as carapace width, CW) existed between both clutches. Each clutch of juveniles was observed during a 1-year period, recording the percentage of molted crabs, intermolt period and percentual increment of size after each molting. At the end of the observation period, males and females from the October clutch reached the size of sexual maturity, while crabs of the remaining clutch did not. This difference was due to the higher increment in size of the October crabs at the third and fourth molts, compared to the February ones. Such difference seems to be related to an increase in reproductive effort during the breeding season, once the sexual maturity was attained.
\end{abstract}

Key words: somatic growth, juveniles, crabs, laboratory conditions.

\section{Crecimiento somático en juveniles del cangrejo de estuario Chasmagnathus granulata Dana 1851 (Brachyura, Grapsidae), bajo condiciones de laboratorio}

RESUMEN: Se recolectaron en Bahía Samborombón (Argentina), ejemplares juveniles de ambos sexos de la especie Chasmagnathus granulata, durante octubre de 1994 y febrero de 1995 ; estos meses corresponden, respectivamente, al inicio y al final del período reproductivo de la especie. No se hallaron diferencias entre lotes para el ancho inicial de caparazón (CW). Cada lote de cangrejos juveniles fue observado durante un año en condiciones de laboratorio, registrándose el porcentaje de cangrejos mudados, período de intermuda e incremento porcentual de talla luego de cada muda. Al finalizar el período de observación, machos y hembras del lote de octubre alcanzaron la talla de madurez sexual mientras que los del lote de febrero no consiguieron alcanzar esa talla. Esta diferencia se debió al mayor incremento de talla de los cangrejos del lote de octubre en su tercera y cuarta muda, comparados con los cangrejo del otro lote. Tal diferencia parece estar relacionada con un incremento del esfuerzo reproductivo durante el período reproductivo, una vez alcanzada la madurez sexual.

Palabras claves: crecimiento somático, juveniles, cangrejos, condiciones de laboratorio.

\section{INTRODUCTION}

Tissue growth is essentially a continuous process in Crustacea, although the increase in body size is a discontinuous one, which involves a series of integument molts allowing a rapid increase in body size before the new cuticle hardens and becomes rigid (Hartnoll, 1982; 1983). Growth can be estimated by several methods, such as: molt increment (increase in size at molting) together with frequency of molting (Hyatt, 1948 ; Spivak,1988), observations of age and size (Oliva et al., 1997), mark-recapture observations (Arana, 1992 ; Lovrich and Vinuesa, 1995) and statistical analysis of size 
frecuency data (D'Incao et al, 1993 ; Roa and Bahamonde, 1993 ; Oliva et al., 1997). These studies are also important tools for understanding population dynamic of marine species and for recommending alternative strategies for exploitation and management of marine resources (Arana, 1992 ; Roa and Bahamonde, 1993 ; Lovrich and Vinuesa, 1995 ; Oliva et al, 1997).

Different patterns of growth in juvenile stages have been extensively studied in relation with the acquisition of sexual maturity (Hartnoll, 1974; 1978). Larvae, juveniles or adults of a particular species may exhibit different growth patterns (Hartnoll, 1965 ,1982, 1983 ; Felder et al, 1985 ; Fukui, 1988). Growth, survival and feeding rate of larvae and juveniles can be modulated by temperature (Klein Breteler, 1975 ; Kondzela and Shirley, 1993 ; Wainwright and Armstrong, 1993). This could explain why the age at sexual maturity of some crustaceans, or their incorporation to the commercial fishery, may vary with location (Hines, 1989 ; Kondzela and Shirley, 1993 ; Stevens, 1990).

Chasmagnathus granulata (Decapoda, Brachyura, Grapsidae) is an intertidal estuarine crabs from salt marsh environments along the Atlantic coast of Argentina, Uruguay and southern Brazil. In Samborombón Bay ( $36^{\circ} 18^{\prime} \mathrm{S}, 56^{\circ} 48^{\prime} \mathrm{W}$, Argentina), the reproductive season of this species comprises the spring and summer months, i.e., September to March (Rodríguez, 1991), and even extent to April (unpublished observations). Each female can spawn up three or four times during the reproductive period, with an egg incubation period of nearly a month (López, 1997). By this way, females can produce more than one cohorts during the same reproductive period. After four zoea instars (Boschi et al., 1967), the megalopa stage reaches the coastline for molting to the first juvenile instar. Juveniles successively molt to reach the size of sexual maturity (López et al., 1997) and thus the beginning of the adult condition.

The growth rate of $C$. granulata (Bertalanffy growth rate curves) has been studied from crabs sampled at Lagoa dos Patos, Brazil (D' Incao et al, 1993). The present work was aimed at evaluating the somatic growth of $C$. granulata juvenile crabs from Samborombón Bay, during 1 year and under controlled conditions. We have also tried to evaluate if juvenile crabs of the same size, but sampled at the beginning or end of the reproductive season, are equally able to reach the mature size in the next reproductive period.

\section{MATERIALS AND METHODS}

Males and females juvenile crabs were collected at Faro San Antonio beach, southern edge of Samborombón Bay on two dates: October 1994 and February 1995. Number of collected crabs, together with the mean carapace width at the beginning of experiments, are listed in Table 1. Carapace width $(\mathrm{CW})$ was always measured behind the third cephalothoracic spine (maximum $\mathrm{CW}$ ). Because of their sizes, selected crabs necessarily hatched as larvae in the previous reproductive period they were sampled (Boschi et al., 1967). The size of employed crabs were also below the size at sexual maturity reported previously, according to changes in allometric growth of secondary reproductive characters (López et al., 1997).

Once in the laboratory, a two week acclimation period took place, under the same environmental conditions to be used later during the experiments. These experiments comprised a 1 year observation period. Each crab was isolated in a plastic container of $200 \mathrm{ml}$ capacity, filled with $30 \mathrm{ml}$ of artificial saline water at $12 \%$ o salinity (HW Germany salts added to dechlorinated tap water) renewed twice a week after feeding. Temperature was always maintained at $20 \pm 1^{\circ} \mathrm{C}$, while photoperiod was kept at 14:10 L:D from September to March (the reproductive months) or 12:12 L:D during the rest of the year. Crabs were fed ad libitum twice a week on pellets of rabbit food with the following composition (in relation to wet weight): protein $17 \%$, fat $3 \%$, fiber $15 \%$, digestible energy $2700 \mathrm{kcal} / \mathrm{kg}$. All crabs were daily examined, recording the following events: occurrence of molt, date of molting and size $(\mathrm{CW})$ after molting.

The observation period began on October 10th and February 20th, for crabs sampled on October 1994 (clutch 1) and February 1995 (clutch 2) respectively. The initial size of crabs, for males and females, was compared between clutches by Student $\mathrm{t}$ - test.

Percentage of molted crabs, intermolt period and percentual increment of size after each molting were estimated from recorded data. Pre-molt size was measured in the exuvia, while the post-molt size was measured in hardened, 20-d post-molted crabs, by means of a vernier caliper (precision $0.02 \mathrm{~mm}$ ). The percentual increment of size (\%inc) was calculated as follows : 
$\%$ Inc $=\frac{\text { Post-molt size }(\mathrm{CW})-\text { Pre-molt size }(\mathrm{CW}) \times 100}{\text { Pre-molt size }(\mathrm{CW})}$

while the annual size increment (\%Ann-Inc) was calculated as:

$$
\% \text { Ann-Inc }=\frac{\text { FCW }- \text { ICW }}{\text { ICW }} 100
$$

where FCW: final carapace width (one year after the beginning of the experiment) and ICW: initial carapace width (at the beginning of the experiment)

No determination of crab weight was made. Fisher exact test was used to compare proportions of molted crabs between sexes or clutches. Chisquare test was applied for contingency tables greater than 2x2. A two-way ANOVA was applied to analyze time between molts, taking as factors clutch and sex, while the increment of size after molting was analyzed by a two-way ANCOVA test, considering the same factors above mentioned and taking the initial size as the covariables (Sokal and Rohlf, 1979). A significance level of 0.05 was employed for all tests.

\section{RESULTS}

Table 1 shows the final carapace width of crabs, together with the annual increment in $\mathrm{CW}$, i.e. the increment in the size of crabs that were alive at the end of the observation period, regardless of the number of molts they had. Results of the statistical comparisons between sexes and clutches by ANCOVA (Table 1), showed no differences ( $>0.05)$ between sexes but significant ones $(p<0.05)$ between clutches, the higher increment corresponding to the October clutch.

No significant differences ( $>>0.05)$ existed between clutches, as for the initial mean carapace width, neither for males nor for females. As for $\%$ of molted crabs (Table 2), a significant difference $(p<0.05)$ was only found between clutches at the second molt, a higher percentage corresponding to the February clutch. No significant differences ( $>0.05$ ) were in the intermolt period, in neither case. Concerning the increment in $\mathrm{CW}$, no differences existed between sexes, but a significant difference was detected between clutches at the third $(p<0.001)$ and fourth $(\mathrm{p}<0.05)$ molts, the higher increments corresponding to the October clutch (Table 2).

Results of statistical comparisons by Chi-square of the percentages of molt occurrence in regard to season and lunar phase (Table 3), recorded for each clutch during the complete 1-year observation period, indicated that no significant differences between clutches were evident neither for seasons

Table 1. Mean carapace width and number of Chasmagnathus granulata (initial values). SE: standard error of mean; ICW: initial carapace width; Ni: initial number of crabs; FCW: final carapace width; Na and \% AnnualInc: number of alive crabs and annual size $(\mathrm{CW})$ increment at the end of the 1-year observation period, respectively. ANCOVA results of comparing FCW (taking ICW as covariable) between clutches and sexes are also indicated.

Tabla 1. Ancho de caparazón promedio y número de ejemplares de Chasmagnathus granulata (valores iniciales). SE: error estandar de la media ; ICW: ancho inicial de caparazón; FCW: ancho final de caparazón; Na and \% Ann-Inc: número de cangrejos vivos e incremento anual de talla $(\mathrm{CW})$ al final del período de observación de 1 año, respectivamente. se indican los resultados de la comparación por ANCOVA de FCW (tomando ICW como covariable) entre lotes y sexos.

\begin{tabular}{|c|c|c|c|c|c|c|c|}
\hline Clutch & Sex & $\mathbf{I C W} \pm \mathbf{S E}$ & $\mathbf{N i}$ & $\mathbf{F C W} \pm \mathbf{S E}$ & $\mathbf{N a}$ & $\%$ Ann-Inc \pm SE & $\mathbf{p ~ v a l u e}$ \\
\hline 1 (October) & males & $12.45 \pm 0.31$ & 13 & $18.83 \pm 0.76$ & 7 & $52.83 \pm 6.54$ & $\begin{array}{c}\text { between } \\
\text { clutches } \\
(\mathrm{p}<0.001)\end{array}$ \\
\cline { 2 - 7 } & females & $12.74 \pm 0.54$ & 11 & $19.95 \pm 0.65$ & 6 & $56.84 \pm 7.73$ & \\
\hline 2 (February) & males & $11.71 \pm 0.33$ & 40 & $15.59 \pm 0.40$ & 26 & $38.18 \pm 3.46$ & $\begin{array}{c}\text { between } \\
\text { sexes } \\
\text { (p>0.05) }\end{array}$ \\
\cline { 2 - 7 } & females & $12.31 \pm 0.23$ & 60 & $15.73 \pm 0.34$ & 35 & $34.06 \pm 3.21$ & \\
\hline
\end{tabular}


Table 2. Percentages of molted crabs, time between molts (days) and percentages of size increment for both juvenile clutches of $C$. granulata; \% molted.: percentage of molted crabs, always on the initial crab number (see Table 1); $T_{i, m} \pm$ SE: mean time of intermolt (since the previous one) \pm standard error of mean; \% Inc. \pm SE: mean percentage of $\mathrm{CW}$ increment \pm standard error of mean. N.D.: not determined; $p$ values are indicated for the statistical comparisons between sexes and clutches.

Tabla 2. Porcentaje de cangrejos mudados, tiempo entre mudas (días), porcentajes de incremento de talla y resultado de las comparaciones estadísticas entre sexos y lotes para cangrejos juveniles de $C$. granulata: \% molted: porcentaje de cangrejos mudados (referidos al número inicial, ver tabla 1 ); $T_{i} . \pm$ SE: valor medio de intermuda (desde el evento previo) \pm error estandar de la media ; \% Inc. \pm SE : incremento porcentual medio en el ancho de caparazón \pm error estandar de la media; N.D.: no determinado; se indican los valores de p de las comparaciones estadísticas entre sexos y lotes.

\begin{tabular}{|c|c|c|c|c|c|c|c|}
\hline \multirow[t]{2}{*}{ Molt event } & \multirow[t]{2}{*}{ Variable } & \multicolumn{2}{|c|}{ Clutch 1} & \multicolumn{2}{|c|}{ Clutch 2} & \multirow{2}{*}{$\begin{array}{c}\text { between } \\
\text { sexes }\end{array}$} & \multirow{2}{*}{$\begin{array}{l}\text { between } \\
\text { clutches }\end{array}$} \\
\hline & & males & females & males & females & & \\
\hline \multirow[t]{3}{*}{ First } & $\%$ molted & 100 & 90.90 & 100 & 100 & $>0.990$ & 0.19 \\
\hline & $\mathrm{T}_{\mathrm{i} . \mathrm{m} .} \pm \mathrm{SE}$ & N.D. & N.D. & N.D. & N.D. & N.D. & N.D. \\
\hline & $\%$ Inc. $\pm \mathrm{SE}$ & $10.85 \pm 0.93$ & $9.97 \pm 0.82$ & $10.71 \pm 0.66$ & $10.84 \pm 0.61$ & 0.87 & 0.79 \\
\hline \multirow[t]{3}{*}{ Second } & $\%$ molted & 92.30 & 72.70 & 100 & 96.70 & 0.24 & 0.01 \\
\hline & $\mathrm{T}_{\mathrm{i} . \mathrm{m} .} \pm \mathrm{SE}$ & $91.10 \pm 7.50$ & $112 \pm 5.30$ & $108.70 \pm 8.60$ & $101.90 \pm 5.70$ & 0.53 & 0.74 \\
\hline & $\%$ Inc. $\pm \mathrm{SE}$ & $13.13 \pm 1.04$ & $17.75 \pm 1.98$ & $12.94 \pm 1.02$ & $14.44 \pm 0.79$ & 0.06 & 0.05 \\
\hline \multirow[t]{3}{*}{ Third } & $\%$ molted & 92.30 & 72.70 & 57.50 & 68.30 & 0.85 & 0.09 \\
\hline & $\mathrm{T}_{\mathrm{i} . \mathrm{m} .} \pm \mathrm{SE}$ & $105.90 \pm 9.30$ & $104.80 \pm 8.60$ & $113.40 \pm 10.0$ & $107.20 \pm 5.30$ & 0.71 & 0.62 \\
\hline & $\%$ Inc. $\pm \mathrm{SE}$ & $14.78 \pm 1.26$ & $15.82 \pm 0.62$ & $9.42 \pm 0.91$ & $10.81 \pm 0.65$ & 0.17 & $<0.001$ \\
\hline \multirow[t]{3}{*}{ Fourth } & $\%$ molted & 30.80 & 9.10 & 22.50 & 15 & 0.17 & 0.77 \\
\hline & $\mathrm{T}_{\mathrm{i} . \mathrm{m} .} \pm \mathrm{SE}$ & $103.50 \pm 8.14$ & $93.00 \pm 0.00$ & $104.10 \pm 9.20$ & $91.60 \pm 11.00$ & 0.66 & 0.46 \\
\hline & $\%$ Inc. \pm SE & $12.67 \pm 1.66$ & $14.50 \pm 0.00$ & $9.67 \pm 1.41$ & $12.29 \pm 1.27$ & 0.60 & 0.04 \\
\hline
\end{tabular}

Table 3. Percentages of molting by season and lunar phase, for each clutch of Chasmagnathus granulata. Nm: number of molts. LQM: last quarter moon, NM: new moon, FQM: first quarter moon, FM: full moon.

Tabla 3. Porcentajes de mudas por estación y fase lunar, para cada lote de chasmagnathus granulata. Nm: número de mudas. LQM: luna cuarto menguante, NM: luna nueva, FQM: luna cuarto creciente, FM: luna llena.

\begin{tabular}{|c|c|cccc|cccc|}
\hline \multirow{2}{*}{ Clutch } & \multirow{2}{*}{ Nm } & \multicolumn{4}{|c|}{ Season } & \multicolumn{4}{c|}{ Lunar phase } \\
\cline { 3 - 9 }$y$ & Spring & Summer & Autumn & Winter & LQM & NM & FQM & FM \\
\hline October & 69 & 33.30 & 18.80 & 27.50 & 20.30 & 29.00 & 30.40 & 23.20 & 17.40 \\
February & 278 & 22.70 & 11.90 & 37.80 & 27.70 & 32.70 & 31.30 & 20.50 & 15.50 \\
\hline
\end{tabular}

$(\mathrm{p}=0.062)$ nor for lunar phases $(\mathrm{p}=0.902)$. Most of molting events occurred at night.

\section{DISCUSSION}

Juvenile crabs usually grow at a higher rate than adults, i.e. the percentage increment in body size declines as the size of crabs increases (Hartnoll, $1982 ; 1983)$. This relative rapid growth of juveniles would be relevant for their efficient recruitment to the reproductive stock of the species, the growth rate depending on the availability of food among other factors (Sastry, 1983). In general terms, the significance of environmental signals to the 
neuroendocrine mechanisms that regulate growth and maturation of juvenile crabs is far to be well established.

We have observed up to four consecutive molts of the juvenile crabs assayed, being more frequently three molts as maximum, at least under the laboratory conditions maintained during the 1-year observation period. Nevertheless, extrapolation of these results to a field situation should be done carefully. In this regard, we have no information about the annual number of molts, neither about the temporal distribution of molting throughout the year, for crabs in their natural environment. It is well known that low temperatures may inhibit the molting process in crabs (Hyatt, 1948; Boschi et al, 1967; Tsuchida and Watanabe, 1997). Ambient temperature in Samborombón Bay annualy ranges from 8.2 to $23.3^{\circ} \mathrm{C}$ (Piccolo and Perillo, 1997), the mean being significantly lower than the constant we maintained in the laboratory during the entire observation period. According to Boschi et al, (1967) a laboratory temperature ranging $12-17^{\circ} \mathrm{C}$ could be responsible of the "slow growth" of small C. granulata juvenile crabs. Nevertheless, juvenile and early adults of the grapsid crab Cyrtograpsus angulatus, who lives in the same environments that C. granulata, molted throughout the year, both in field and laboratory conditions (Spivak, 1988).

Besides temperature, other factors can affect the process and the timing of molting in the field and in the laboratory. Nutrition often appears to be the dominant factor in postlarval growth (Felder et al., 1985). Food is the main growth determinant in the field for juvenile and adult crabs of Aratus pisonii (Conde and Díaz, 1989) and for Carcinus maenas juveniles, to whom the interaction between food and temperature, under laboratory conditions, seemed to affect the size increment with molting and the intermolt period (Klein Breteler, 1975).

The seasonal ecdisis pattern of $C$. granulata juvenile crabs has shown to be quite different from the adult pattern, since the former molted throughout the year while the latter mainly during April and May, at the same experimental conditions as the juveniles (López, 1997). Since somatic growth and reproduction have been recognized as antagonistic events in adult crabs (Adiyodi, 1988), they molt once the reproductive period has ended, while juveniles molt during the entire year. In the case of Paralomis granulosa, while adult crabs only molted during spring and summer, juveniles also molted during winter (Lovrich and Vinuesa, 1995).

There have been described diary and seasonal patterns of ecdysis in crustaceans. As observed in our experiments, molting at night could minimize the effect of cannibalism and has been also reported for the grapsid crabs Pachygrapsus crassipes (Hyatt, 1948) and Cyclograpsus punctatus (Broekhuysen, 1941), and for other decapod crustaceans (Broekhuysen, 1941; Skewes et al, 1994; Dworschak, 1988; Mac Diarmid, 1989). We have also observed a close correlation between the timing of molting and the lunar cycle. Juvenile crabs mainly molted during the less shining phases, likely to minimize the risk of predation or cannibalism. Interestingly, this molting rhythm was maintained under constant laboratory conditions (as for temperature and photoperiod). The crab Carcinus maenas showed both a circadian and circatidal rhythm of ecdisis, related to the minimization of cannibalism and to the juvenile recruitment (Zeng et al., 1997).

The size increment after molting we have recorded in C. granulata $(9,67$ to $17,75 \%$ of the premolt carapace width) was similar to that of other juvenile grapsid, semiterrestrial crabs (Table 4). Size increment of those species, was always lower than that showed by crabs from strictly aquatic environments (specially Majidae, Cancridae and Portunidae) and greater than that of terrestrial crabs (Hartnoll, 1965). Comparing the intermolt periods recorded for the $C$. granulata juvenile crabs with those of other juvenile grapsid crabs showed a high degree of variability, as reported in Table 5.

In accordance with the reported for other grapsid crabs like $P$. crassipes, A. pisonii, Sesarma ricordi, Pachygrapsus transversus, Pachygrapsus gracilis y Cyclograpsus integer (Hartnoll, 1965; Fukui, 1988; Warner, 1967) no difference between sexes were noted in the size increment of $C$. granulata juveniles. Once the sexual maturity is achieved, the mentioned species showed differential somatic growth between sexes (females growing lesser than males).

The reproductive size of the $C$. granulata was previously determined, for both sexes (López et al. 1997). For males, the body size associated with a change in the relative growth of reproductive characters was $16.50 \mathrm{~mm} \mathrm{CW}$, this size seems to be the functional maturity one, since mating was observed just above it. As for females, mature ovaries were observed at $19.00 \mathrm{~mm} \mathrm{CW}$, the smallest 
Table 4. Size increment after molting in juvenile grapsid crabs.

Tabla 4. Incrementos de talla después de la muda en juveniles del cangrejo de estuario.

\begin{tabular}{|c|c|c|}
\hline Species & Size increment $(\%)$ & Reference \\
\hline Chasmagnathus granulata & $9.7-17.8 \%$ & This study \\
\hline Pachygrapsus crassipes & 14-29 both sexes & Hyatt, 1948 \\
\hline Pachygrapsus marmoratus & $15 \%$ both sexes & Vernet and Charmantier-Daures, 1994 \\
\hline Cyclograpsus punctatus & $9-20$ both sexes & Broekhuysen, 1941 \\
\hline Cyrtograpsus angulatus & $\begin{array}{l}\text { 16- } 24 \text { males } \\
17-22 \text { females }\end{array}$ & Spivak, 1988 \\
\hline Eriocheir sinensis & nearly 6 both sexes & Vernet and Charmantier-Daures, 1994 \\
\hline Sesarma jarvisi & 11.2 both sexes & Diesel and Horst, 1995 \\
\hline Hemigrapsus sanguineus & $17.4-30$ & Fukui, 1988 \\
\hline Hemigrapsus penicillatus & & Fukui, 1988 \\
\hline Gaetice depressus & & Fukui, 1988 \\
\hline Acmaeopleura parvula & & Fukui, 1988 \\
\hline Nanosesarma gordoni & & Fukui, 1988 \\
\hline
\end{tabular}

Table 5. Intermolt period of juvenile grapsid crabs.

Tabla 5. Período de intermuda en juveniles del cangrejo de estuario.

\begin{tabular}{|l|c|c|}
\hline \multicolumn{1}{|c|}{ Species } & Intermolt period (days) & reference \\
\hline Gaetice depressus & $4-117 *$ & Fukui, 1988 \\
\hline Acmaepleura parvula & $86-211 *$ & Fukui, 1988 \\
\hline Nanosesarma gordoni & $22-53 *$ & Fukui, 1988 \\
\hline Hemigrapsus sanguinolentus & $>200 *$ & Fukui, 1988 \\
\hline Cyclograpsus punctatus & $82-130$ & Broekhuysen, 1941 \\
\hline Cyrtograpsus angulatus & $36-50$ & Spivak, 1988 \\
\hline Pachygrapsus crassipes & $18-30$ & Hyatt, 1948 \\
\hline
\end{tabular}

* Adults also included

size for ovigerous females being $20.28 \mathrm{~mm} \mathrm{CW}$ (López et al., 1997). Although we have not dissected the gonads of juveniles used in the current experiments, it becomes clear in this context that juveniles captured at the beginning of the reproductive season have reached the sexual maturity 1 year later, while juveniles of the same initial size than the former ones, but captured at the end of the reproductive period, did not.

As stated in the Introduction, sampled juveniles from both clutches had necessarily hatched in the previous reproductive season, probably from early and late spawns of females, according to Boschi et al. (1967) and López (1997). Therefore, from our 
results we conclude that a minimum of two and a maximum of three years are needed to reach the sexual maturity from the larval stages. This estimation is similar to that reported for other grapsid crabs (Diesel and Horst, 1995; Fukui, 1988; Tsuchida and Watanabe, 1997). For instance, larvae of Plagusia dentipes (Grapsidae), hatched at the beginning of the reproductive period, acquire the sexual maturity nearly one year before than those larvae hatched at the end of the same reproductive period. As a result, both cohorts differ in size at the onset of sexual maturity. As size is a major determinant of crab fecundity (Hines, 1982,1988), the fecundity of both cohort differs (Tsuchida and Watanabe, 1997) .

Adult females of $C$. granulata are able to have up to four spawning during a reproductive period (López, 1997). Juveniles sampled in October would have the opportunity to reproduce more than once during the next reproductive season if they reached the sexual maturity in one year, as it was the case according to our experimental results. Even presenting a similar growth rate, juveniles collected in February would have reached the sexual maturity only by the end of the next reproductive period, thus having the chance for only one reproductive event. In fact, they grew at a lower rate that the October juveniles. Therefore, we believe that an extra energy investment for growth takes place in juveniles that can reach the sexual maturity at the beginning of a reproductive period, perhaps as part of a strategy to maximize the efficiency of juvenile recruitment to the reproductive stock and thus, as a way of optimizing the reproductive investment of the species.

The difference encountered between clutches was related to the size increment at molting, instead of percentual of molted crabs or intermolt period. Such difference did not seem to be related to fluctuations in physical or abiotic factors, since temperature, salinity, quantity and quality of food were maintained at a same constant level during the entire year comprised by each one of the clutches. Some environmental cues received by juvenile crabs during their recent history, i.e. previously to their sampling at the beginning or end of the reproductive period of the species, seems to be crucial for determining the subsequent molting pattern.

Besides, the "advantage" taken by the October clutch in size increment took place at the third molt (eventually the fourth as well). The higher photoperiod maintained in the laboratory during spring and summer (14L:10D), than during autumn and winter (12L:12D), did not seem to act as an environmental cue to trigger the observed difference in size increment, since the third molt of October juveniles occurred in the winter while the third molt of the other clutch took place during spring. Perhaps, the natural photoperiod or other stimulus were relevant as triggers at sampling dates. Even an endogenous component might be acting, since juveniles hatched as larvae, but the nature of these mechanisms should be subject of further research.

\section{ACKNOWLEDGEMENTS}

This grant was supported by a grant from the University of Buenos Aires (UBACYT 94-97).

\section{REFERENCES}

Adiyodi, R.G. 1988. Reproduction and Development. In: W. W. Burgreen \& B.R. McMahon, (eds.). Biology of the Land Crabs, Cambridge University Press, p.p. 139-185.

Arana Espina, P. 1992. Desplazamientos de la langosta de Juan Fernández (Jasus frontalis H. Milne Edwards, 1837), determinados a través de marcaje. Cienc. Tec. Mar. Cona, 15: 49-75.

Boschi, E.; Scelzo, M. and B. Goldstein.1967. Desarrollo larval de dos especies de Crustáceos Decápodos en el laboratorio: Pachycheles haigae Rodrigues da Costa (Porcellanidae) y Chasmagnathus granulata Dana (Grapsidae). Bol. Inst. Biol. Mar. Mar del Plata, Argentino, 12: 1-46.

Broekhuysen, G. 1941. The life-history of Cyclograpsus punctatus, M. Edw.: Breeding and Growth. Trans. R. Soc. S. Afr., 28: 331-366.

Conde, J. E. and H. Díaz. 1989. Productividad del habitat e historias de vida del cangrejo de mangle Aratus pisonii H. Milne Edwards (Brachyura, Grapsidae). Bol. Inst. Oceanogr. Venezuela Univ. Oriente 28 (1y 2): 113-120.

Diesel, R. and D. Horst. 1995. Breeding in a snail shell: ecology and biology of the jamaican crab Sesarma jarvisi (Decapoda: Grapsidae). J. Crust. Biol., 15(1): 179-195. 
D'Incao, F.; Rufino, M. L.; Da Silva, K. G.; Da Costa Braga, A. and L. Cunha Marques. 1993. Crescimento de Chasmagnathus granulata Dana, 1851, em um marisma do estuário da Lagoa dos Patos, RS (Decapoda: Grapsidae). Rev. Brasil. Bio. 53: 637-643.

Dworschak, P.C. 1988. The Biology of Upogebia pusilla (Petagna) (Decapoda, Thalassinidea). III Growth and Production. Mar. Ecol., 9(1): 51-77.

Felder, D. L. ; J. W. Martin and J. W. Goy. 1985. Patterns in early postlarval development of decapods. In: A.M. Wenner (ed). Crustacean Issues II. Larval Growth. Balkema, Boston, p.p. 163-225.

Fukui, Y. 1988. Comparative studies on the Life History of the Grapsid Crabs (Crustacea, Brachyura) Inhabiting Intertidal Cobble and Boulder Shores. Publ. Seto Mar. Biol. Lab., 33(4/ 6): 121-162.

Hartnoll, R. 1965. Notes on the marine grapsid crabs of Jamaica. Proc. Linn. Soc. Lond., 176 (2): 113147.

Hartnoll, R. 1974. Variation in growth pattern between some secondary sexual characters in crabs (Decapoda, Brachyura). Crustaceana, 27: 131-136.

Hartnoll, R. 1978. The determination of relative growth in crustacea. Crustaceana, 34: 281-293.

Hartnoll, R.1982. Growth. In: D.E. Bliss (ed.). The Biology of Crustacea. Academic Press, New York, Vol 2, p.p. 111-196.

Hartnoll, R. 1983. Strategies of Crustacean Growth. Aust. Mus. Syd. Mem., 18: 121-131.

Hines, A. H. 1982. Allometric constraints and variables of reproductive effort in brachyuran crabs. Mar. Biol. 69: 309-320.

Hines, A. H. 1988. Fecundity and reproductive output in two species of deep-sea crabs, Geryon fenneri and G. quinquedens (Decapoda: Brachyura). J. Crust. Biol. 8: 557-562.

Hines, A. H. 1989. Geographic variation in size at maturity in brachyuran crabs. Bull. Mar. Sci. 45(2): 356-368.

Hyatt, R. 1948. The biology of the lined shore crab Pachygrapsus crassipes Randall. Pacif. Sci., 2: 135-213.
Klein Breteler, W. C. M. 1975. Laboratory experiments on the influence of environmental factors on the frequency of moulting and the increase in size at moulting of juvenile shore crabs, Carcinus maenas. Neth. J. Sea Res. 9: 100-120.

Kondzela, C.M. and T.C. Shirley. 1993. Survival, feeding, and growth of juvenile dungeness crabs from southeastern Alaska reared at different temperatures. J. Crust. Biol. 13(1): 25-35.

López, L. 1997. Adquisición de la madurez sexual y caracterización del patrón de crecimiento y reproducción en Chasmagnathus granulata, DANA 1851 (Brachyura, Grapsidae, Sesarminae) de Bahía Samborombón, Buenos Aires, Argentina. Tesis Doctoral, Universidad de Buenos Aires, 244 pp.

López, L.; Stella, V. and E. Rodríguez. 1997. Size at onset of sexual maturity in Chasmagnathus granulata. Nauplius 5(2). In press.

Lovrich, G. A. and J. H. Vinuesa. 1995. Growth of inmature false southern crab, Paralomis granulosa (Anomura, Lithodidae) in the Beagle Channel, Argentina. Sci. Mar. 59(1): 87-94.

Mac Diarmid, A. B. 1989. Size at onset of maturity and size-dependent reproductive output of female and male spiny lobsters Jasus edwardsii (Hutton) (Decapoda, Palinuridae) in northern New Zealand. J. Exp. Mar. Biol. Ecol., 127: 229-243.

Oliva Núñez, J.; Arana Espina, P. and A. González Ynope. 1997. Crecimiento y mortalidad del "cangrejo violáceo" Platyxanthus orbignyi en la zona costera de Lambayeque, Perú. Inf. Inst. Mar Perú, 126: 55-74.

Piccolo, M.C. and G. M. Perillo. 1997. Geomorfología e hidrografía de los estuarios. In: Boschi (ed.) El Mar Argentino y sus recursos pesqueros. Tomo 1. Antecedentes históricos de las exploraciones en el mar y las características ambientales. Mar del Plata, Argentina, p.p. 133-161.

Roa, R. and R. Bahamonde. 1993. Growth and expansion of an exploited population of the squat lobster (Pleurocodes monodon) after 3 years without harvesting. Fish. Res., 18: 305-319.

Rodríguez, E. M. 1991. Efectos letales y subletales de dos plaguicidas sobre las especies $U c a$ uruguayensis y Chasmagnathus granulata (cangrejal bonaerense). Tesis Doctoral, 1991, Universidad de Buenos Aires, Argentina, 219 págs. 
Sastry, A. 1983. Ecological Aspects of Reproduction. In: D.E. Bliss (ed.). The Biology of Crustacea. Academic Press, New York., p.p. 179-269.

Skewes, T. D.; Pitcher, C. R. and J. T. Trendall. 1994. Changes in the size structure, sex ratio and molting activity of a population or ornate rock lobsters, Panulirus ornatus, caused by an annual maturation molt and migration. Bull. mar. Sci. 54(1): 38-48.

Sokal, R. and F. Rohlf. 1979. Biometría. Principios y métodos estadísticos en la investigación biológica. H. Blume, Madrid, 832 pp.

Spivak, E. 1988. Moult and growth in Cyrtograpsus angulatus Dana (Decapoda, Brachyura). J. Nat. Hist., 22: 617-629.

Stevens, B. G. 1990. Temperature-dependent growth of juvenile red king crab (Paralithodes camtschatica) and its effects on size-at-age and subsequent recruitment in the eastern Bering sea. Can. J. Fish. Aquat. Sci., 47: 1307-1317.
Tsuchida, S. and S. Watanabe. 1997. Growth and reproduction of the grapsid crab Plagusia dentipes (Decapoda: Brachyura). J. Crust. Biol., 17(1): 9097.

Vernet, G. and M. Charmantier-Daures. 1994. Mue, Autotomie et règènèration $I n$ : Masson (ed.) Traité de Zoologie. Anatomie, Systématique, Biologie. Tome VII, Fascicule I: Crustacés. Morphologie, Physiologie, Reproduction, Systématique. Paris, France, p.p 107-155.

Wainwright, T.C. and D.A. Armstrong. 1993. Growth patterns in the dungeness crab (Cancer magister Dana): synthesis of data and comparison of models. J. Crust. Biol. 13(1): 36-50.

Warner, G. 1967. The life history of the mangrove tree crab Aratus pisonii. J. Zool. Lon., 153: 321335.

Zeng, C., Naylor, E. and P. Abello. 1997. Endogenous control of timing of metamorphosis in megalopae of the shore crab Carcinus maenas. Mar. Biol. 128: 299-305.

Recibido el 6 de enero de 1998.

Aceptado el 2 de julio de 1998. 